\title{
Pore structure effects on the kinetics of methanol oxidation over nanocast mesoporous perovskites
}

\author{
Mahesh M. Nair a, Freddy Kleitz a, Serge Kaliaguine b,* \\ a Department of Chemistry and Centre de Recherche sur les Matériaux Avancés (CERMA), Université Laval, Quebec City, G1V 0A6, Canada \\ ${ }^{\mathrm{b}}$ Department of Chemical Engineering, Université Laval, Quebec City, G1V 0A6, Canada
}

\section{A R T I C L E I N F O}

\section{Article history:}

Received 21 March 2015

Accepted 3 May 2015

Published 5 January 2016

\section{Keywords:}

Mesoporous perovskites

High surface area

Nanocasting

Methanol oxidation

Kinetics

\begin{abstract}
A B S T R A C T
Mesoporous $\mathrm{LaMnO}_{3}$ perovskite catalysts with high surface area were synthesized by using the recently developed hard templating method designated as "nanocasting". Ordered mesoporous silica designated as SBA- 15 was used as the hard template. It was found that the surface area of the nanocast perovskites can be tuned $\left(80-190 \mathrm{~m}^{2} / \mathrm{g}\right.$ ) by varying the aging temperature of the SBA- 15 template. Nanocast $\mathrm{LaMnO}_{3}$ catalysts showed high conversion efficiencies for the total oxidation of methanol under steady state conditions, the one with the highest value of surface area being the best catalysts, as expected. Kinetic studies were performed for all of the synthesized catalysts. Rate constants were found to vary in accordance with the specific surface area of the nanocast catalyst which depends on the aging temperature of the parent template. From the rate constants obtained from experimental conversions at various space velocities (19500 to $78200 \mathrm{~h}^{-1}$ ), values of activation energy and pre-exponential factor for the three nanocast $\mathrm{LaMnO}_{3}$ catalysts were determined by the linear regression of the Arrhenius plot. It is observed that the activation energy for all the catalysts remain constant irrespective of the variation in specific surface area. Further, a linear relationship was found to exist between the pre-exponential factor and specific surface areas of the catalysts indicating that the rates per unit surface area remains the same for all the catalysts.
\end{abstract}

(C) 2016, Dalian Institute of Chemical Physics, Chinese Academy of Sciences. Published by Elsevier B.V. All rights reserved.

\section{Introduction}

Development of strategies in order to limit the emission of toxic gases such as volatile organic compounds (VOC) from industrial processes is one of the major challenges of the present time. It is desirable to develop environmentally friendly technologies to eliminate pollutants without resulting in further toxic by-products. Thermal combustion is effective; however, using a catalyst can result in much better conversion rate at a comparatively lower temperature by altering the kinetics. For this reason, various scientific efforts were made to develop novel catalytic materials for that purpose [1,2]. Even though noble metals were found to be effective in most of the reactions concerned, it is not at all a cost effective solution from an industrial perspective. Interestingly, perovskite structured mixed metal oxides $\left(\mathrm{ABO}_{3}\right)$ were found to be as effective as noble metals for various catalytic partial or total oxidation reactions especially those of hydrocarbons and volatile organic compounds $[3,4]$. However, the applicability of these materials is not yet fully exploited since the high temperature $\left(>700{ }^{\circ} \mathrm{C}\right)$ conditions used in the synthesis of these materials result in very low specific surface area $\left(<30 \mathrm{~m}^{2} / \mathrm{g}\right)[4-8]$. Hence a major

\footnotetext{
* Corresponding author. Fax: +1-418-6563810; E-mail: serge.kaliaguine@gch.ulaval.ca

This work was supported by the the National Science and Engineering Research Council (Canada), and the Fonds Québécois de la Recherche sur la Nature et les Technologies (Province of Quebec).

DOI: 10.1016/S1872-2067(15)60909-3 | http://www.sciencedirect.com/science/journal/18722067 | Chin. J. Catal., Vol. 37, No. 1, January 2016
} 
milestone that needs to be achieved for the effective utilization of these materials on an industrial scale is the development of a synthesis strategy that helps to achieve higher surface areas. On this regard, Kaliaguine et al. [9] successfully synthesized perovskite oxides with higher surface areas $\left(100 \mathrm{~m}^{2} / \mathrm{g}\right)$ where calcination is performed at temperatures around $200{ }^{\circ} \mathrm{C}$. However, in this case also, the specific surface area was found to decrease at higher calcination temperatures.

The discovery of ordered mesoporous silica and the developments that followed on the research focusing on various mesoporous materials in the past two decades have made it possible to also synthesize various non-siliceous composition materials (carbon, metal oxides, carbides, etc) with extremely high values of specific surface areas $[10,11]$. Out of the methods available for the synthesis of mesoporous materials, nanocasting enjoys a unique position. This method is found to be efficient for developing mono-metallic and/or mixed oxides with high specific surface areas [12-15], which cannot be obtained using other methods. Various studies were performed utilizing the nanocasting approach for the synthesis of a variety of compositions which were successfully utilized for a wide range of applications [16-20, see also literature cited in 15]. Even though these nanocast oxides were examined for a large number of catalytic reactions, most of such studies focused on the measurement of temperature dependent conversions as a function of catalyst composition or surface area [14,21-25]. For the successful employment of these materials in the industry advanced knowledge on the surface reactions as well as the reaction kinetics is required.

We have recently reported the synthesis and catalytic studies of mesoporous perovskite oxides with high specific surface area synthesized using the method of nanocasting [15]. Our studies clearly demonstrated the higher catalytic efficiency of the nanocast perovskites compared to their bulk counterparts synthesized using reactive grinding method and conventional citrate method for various gas phase reactions. To supplement our previous study [15], we report here on the synthesis of high surface area $\mathrm{LaMnO}_{3}$ materials using SBA-15 silica aged at different temperatures $\left(35,100\right.$ and $\left.140{ }^{\circ} \mathrm{C}\right)$ as the hard templates, and discuss the influence of the porosity parameters of the thus-obtained perovskites on their catalytic activity and kinetics. The catalytic properties of these high surface area materials were studied for the total oxidation of methanol. The surface and redox properties of the materials were analyzed using temperature-programmed characterization methods. Detailed kinetic data processing was performed for these materials to achieve a better understanding of the high catalytic efficiencies observed for these new materials.

\section{Experimental}

\subsection{Synthesis of ordered mesoporous SBA-15 silica}

Ordered mesoporous silica SBA-15 hard templates were synthesized according to the previously reported procedure, using Pluronic P123 as the structure-directing agent and tetraethylorthosilicate (TEOS) as the silicon source [26]. In a typical synthesis, $4.0 \mathrm{~g}$ of P123 was dissolved in $76 \mathrm{~g}$ of deionized water and $2.3 \mathrm{~g}$ of hydrochloric acid $(37 \%)$ at $35{ }^{\circ} \mathrm{C}$ under magnetic stirring. To the obtained homogeneous solution, $8.6 \mathrm{~g}$ of TEOS was rapidly added with continued stirring for $24 \mathrm{~h}$ at 35 ${ }^{\circ} \mathrm{C}$ and subsequently subjected to hydrothermal treatment at a desired temperature $\left(35,100\right.$ and $\left.140{ }^{\circ} \mathrm{C}\right)$ for an additional 24 $\mathrm{h}$ to ensure further framework condensation. After cooling, the resulting solution was filtered and the solid products were dried at $100{ }^{\circ} \mathrm{C}$ for $24 \mathrm{~h}$. Finally, the powders were calcined at $550{ }^{\circ} \mathrm{C}$ in order to remove the organic copolymer template.

\section{2. $\quad$ Nanocasting of mesoporous perovskites}

Nanocasting of the mesoporous perovskites was performed by the previously reported procedure using a citrate complex of metal cations as the perovskite precursor and ordered mesoporous silica SBA-15 as the hard template [15]. The precursor was impregnated into the template by using the wet impregnation method. In a typical synthesis, $\mathrm{La}\left(\mathrm{NO}_{3}\right)_{3} \cdot 6 \mathrm{H}_{2} \mathrm{O}$ and $\mathrm{Mn}\left(\mathrm{NO}_{3}\right)_{2} \cdot x \mathrm{H}_{2} \mathrm{O}$ (3 mmol each) were dissolved in an ethanolic solution of citric acid (10 $\mathrm{mL})$ to obtain an equimolar solution, which was added slowly to SBA-15 (1 g) dispersed in water (10 $\mathrm{mL})$. The molar ratio of total metal ions and citric acid was kept at 2:1. The mixture was stirred for a few hours at room temperature, and then the solvent was evaporated under vacuum with a rotary evaporator. The powder thus obtained was further dried at $80{ }^{\circ} \mathrm{C}$ for $24 \mathrm{~h}$, ground well in a mortar, and calcined at $500{ }^{\circ} \mathrm{C}$ for $4 \mathrm{~h}$ to remove the organic part. Impregnation was repeated twice, using for the second time one half of the amount of the precursor, to achieve higher loadings. The final powder was calcined at $700{ }^{\circ} \mathrm{C}$ for $6 \mathrm{~h}$, and the silica template was then removed by treating the composite 3 times with $\mathrm{NaOH}(2 \mathrm{~mol} / \mathrm{L})$ at room temperature. The obtained product was washed with water and ethanol and dried overnight at 80 ${ }^{\circ} \mathrm{C}$. Three syntheses were performed using template SBA-15 aged at 35,100 and $140{ }^{\circ} \mathrm{C}$ and here after, these samples will be denoted as $\mathrm{LaMnO}_{3}-35$, $\mathrm{LaMnO}_{3}-100$ and $\mathrm{LaMnO}_{3}-140$, where the numbers indicate the aging temperature of the SBA-15 template used.

\subsection{Characterization}

Wide-angle powder XRD was performed with a Siemens Model D5000 diffractometer using $\mathrm{Cu} K_{\alpha}$ radiation $(\lambda=0.15496$ $\mathrm{nm}$ ). $\mathrm{N}_{2}$ physisorption analyses were performed at $-196{ }^{\circ} \mathrm{C}$ with an ASAP 2010 sorption analyzer. Prior to analysis, the samples were degassed overnight at $150{ }^{\circ} \mathrm{C}$. Specific surface areas of nanocast perovskites were calculated using the BET method on the lower relative pressure region of the isotherm (0.05-0.2). Pore size distributions were obtained by using the NLDFT method assuming cylindrical pore geometry (applying the kernel of metastable NLDFT adsorption isotherm, i.e., adsorption branch) supplied by the Autosorb-1 1.55 software from Quantachrome Instruments [27-29]. The total pore volume was calculated from the $\mathrm{N}_{2}$ sorption capacity at $p / p_{0}=$ 0.95. Elemental analysis was performed using an M1100 B Perkin-Elmer atomic absorption spectrophotometer. For TEM 
images, the samples were first dispersed in ethanol, deposited on carbon grids and analyzed on a JEOL JEM 1230 microscope.

\subsection{Temperature programmed reduction (TPR) and desorption (TPD)}

A RXM-100 multicatalyst testing and characterization system (Advanced Scientific Design Inc.) was used to perform $\mathrm{O}_{2}$-TPD and $\mathrm{H}_{2}$-TPR. For TPR experiments, the catalyst (50 mg) was placed in a quartz reactor and pretreated under a flow of $20 \mathrm{~mL} / \mathrm{min}\left(20 \% \mathrm{O}_{2}\right.$ in $\left.\mathrm{He}\right)$ at $500{ }^{\circ} \mathrm{C}$ for $1 \mathrm{~h}$. The TPR was performed under a flow of $10 \mathrm{~mL} / \mathrm{min}\left(5 \% \mathrm{H}_{2}\right.$ in $\left.\mathrm{Ar}\right)$ with a temperature ramp of $5{ }^{\circ} \mathrm{C} / \mathrm{min}$ from 25 to $900{ }^{\circ} \mathrm{C}$. The consumption of $\mathrm{H}_{2}$ was monitored and quantified with a thermal conductivity detector (TCD). For $\mathrm{O}_{2}$-TPD, the same pre-treatment was performed as for the TPR experiments and the same amount of the catalyst was used under a flow of $10 \mathrm{~mL} / \mathrm{min}$ of He. A TCD was used for the quantification of the $\mathrm{O}_{2}$ desorbed.

\subsection{Catalytic tests}

The catalytic bed was set up with the catalyst (200 mg) inserted between two quartz wool plugs in a U-shaped quartz reactor (internal diameter $=5 \mathrm{~mm}$ ). The temperature was controlled using a K-type thermocouple placed in the reactor. To purge the catalytic system, the catalysts were first flushed with He for $1 \mathrm{~h}$ at room temperature and then pretreated for $1 \mathrm{~h}$ at $200{ }^{\circ} \mathrm{C}$ before performing the catalytic tests. The feed, composed of $0.5 \% \mathrm{CH}_{3} \mathrm{OH}$ and $5 \% \mathrm{O}_{2}$ in $\mathrm{He}$, was passed through the reactor and the temperature was increased. Gas samples were collected in the steady-state regime after an interval of $2 \mathrm{~h}$ at constant conversion, and the products were analyzed using a gas chromatograph (HP 6890 series) equipped with a TCD. Reactants and products were separated using a Haye-Sep T column (internal diameter $=1 \mathrm{~mm}, \mathrm{~L}=2-5 \mathrm{~m}$ ).

\subsection{Kinetic studies}

To obtain kinetic data, methanol steady-state conversions were monitored for the nanocast mesoporous $\mathrm{LaMnO}_{3}$ catalyst at the reactor outlet at different flow rates $(10-40 \mathrm{~mL} / \mathrm{min}$ corresponding to a gas hourly space velocity of 19500-78200 $\mathrm{h}^{-1}$ ). The obtained experimental conversions were cross-plotted as a function of pseudo-contact time over selected reaction temperatures. The values of reaction rates obtained by the analytical derivatization of the equation corresponding to the fitted curves were evaluated using a simplified equation proposed originally by Arai et al. [4] for the total oxidation of methane.

\section{Results and discussion}

\subsection{Synthesis and characterization of mesoporous perovskites}

The ordered mesoporous SBA-15 silicas synthesized at different aging temperatures used as the hard templates were characterized using $\mathrm{N}_{2}$ physisorption performed at $-196{ }^{\circ} \mathrm{C}$ (see Supporting Information Fig. S.1). Clear indication of variations in pore size, pore volume and surface area was observed in close agreement with the literature [26,29-31]. Using these silica materials as hard templates, a series of $\mathrm{LaMnO}_{3}$ mesoporous perovskites were synthesized. After the removal of the silica template, the presence of the perovskite structure was confirmed in all these materials from the wide angle XRD patterns shown in Fig. 1. No peaks corresponding to crystalline impurities such as mono-metallic oxides of lanthanum or manganese were observed in the wide angle region. Intensity of reflections was higher for $\mathrm{LaMnO}_{3}-35$, most probably because this sample was dominated by non porous bulk particles. A low intensity broad peak around $2 \theta=28^{\circ}$ was observed for all the samples indicating the presence of an X-ray amorphous species; most probably silicates resulting from the incomplete removal of the SBA-15 template. Atomic absorption analysis confirmed the presence of approximately $10 \% \mathrm{Si}$. This might have occurred due to enhanced interactions between the template silica and the rare earth metal in the perovskite structure. The presence of such residual silicate species in nanocast perovskites was documented previously $[14,15]$. Information regarding mesostructural order was obtained from the TEM images, and representative images for all samples are shown in Fig. 2. Well-ordered mesostructural domains were clearly observed for $\mathrm{LaMnO}_{3}-100$ and $\mathrm{LaMnO}_{3}-140$ along with some less defined and disordered nanoporous regions. When SBA-15 aged at $35{ }^{\circ} \mathrm{C}$ was used as the hard template, the presence of ordered regions was comparatively lesser than the other nanocast perovskites.

Further information regarding the porosity and textural parameters was obtained by performing $\mathrm{N}_{2}$ physisorption analysis at $-196{ }^{\circ} \mathrm{C}$ on mesoporous $\mathrm{LaMnO}_{3}$ perovskites synthesized using SBA-15 hard templates aged at different temperatures. The adsorption-desorption isotherms and the corresponding pore size distributions for all these materials are shown in Fig. 3. A type IV behavior was observed for the isotherms. Hysteresis loops appear in the relative pressure range from 0.5 to 1.0 for $\mathrm{LaMnO}_{3}-100$ and $\mathrm{LaMnO}_{3}-140$, which is typical of such mesoporous metal oxides obtained from nanocasting [12,32]. For LaMnO $3-35$ capillary condensation occurs at comparatively

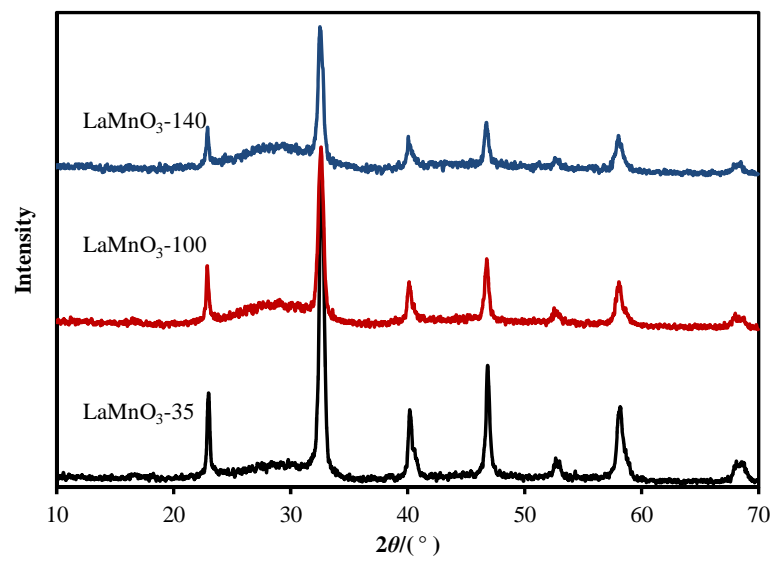

Fig. 1. Wide angle powder XRD patterns of mesoporous $\mathrm{LaMnO}_{3}$ perovskite oxides synthesized using ordered mesoporous SBA-15 aged at 35,100 and $140{ }^{\circ} \mathrm{C}$ as the hard templates. 

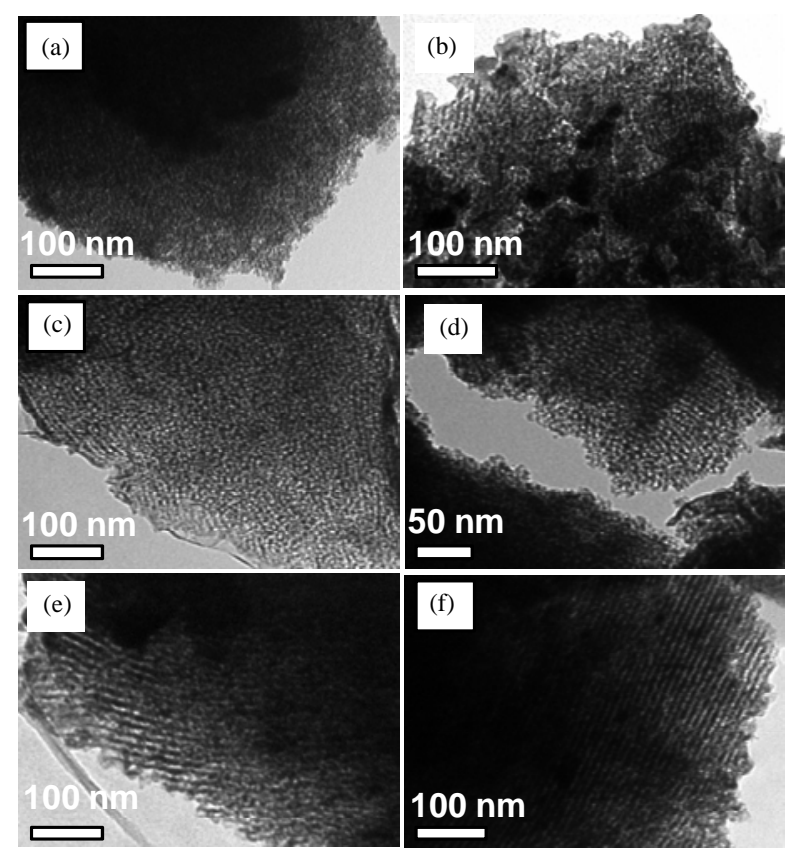

Fig. 2. TEM images of $\mathrm{LaMnO}_{3}-35(\mathrm{a}, \mathrm{b}), \mathrm{LaMnO}_{3}-100$ (c, d) and $\mathrm{LaMnO}_{3}-140(\mathrm{e}, \mathrm{f})$.

higher relative pressure (0.6). Brunauer-Emmett-Teller (BET) specific surface areas obtained for nanocast perovskites are exceptionally high when compared with those of materials obtained by using conventional methods, especially considering the high calcination temperature of $700{ }^{\circ} \mathrm{C}$ (Table 1 ). Variations in specific surface area were observed in the case of nanocast $\mathrm{LaMnO}_{3}$ with respect to the aging temperature of the hard template. A similar trend was observed in the case of NLDFT average pore sizes and pore volumes calculated from the volume adsorbed at the relative pressure of 0.95 . An excellent agreement was observed between the theoretically derived NLDFT isotherms and the experimental isotherms for all the nanocast perovskites in the present study, which validates the use of this method for the pore size determination of the nanocast perovskites (Supporting Information Fig. S.2).

Studies examining the effect of template pore structure on the final nanocast replica were performed by various authors. Rumplecker et al. [32] found that the structure of $\mathrm{Co}_{3} \mathrm{O}_{4}$ replica can be tuned from randomly arranged rods to highly ordered mesoporous network structures depending on interconnectivity of the SBA-15 template, loading of the precursor and impregnation procedure. These authors also confirmed that better replicas were observed by using microwave digested silica template owing to the presence of higher fraction of interconnecting mesopores in the same. Further, Jiao et al. [33] synthesized ordered mesoporous $\mathrm{NiO}$ with a bimodal pore size distribution consisting of a series of small (3.3 nm) and large pores $(11 \mathrm{~nm})$. In this case, the bimodal porosity in nanocast $\mathrm{NiO}$ replica was achieved by varying the degree of microporous bridging between the two sets of mesopores in the ordered mesoporous KIT-6 hard template. Tuysuz et al. [34] performed studies on nanocasting of $\mathrm{Co}_{3} \mathrm{O}_{4}$ using KIT-6 as the hard template. These authors have shown that the textural parameters
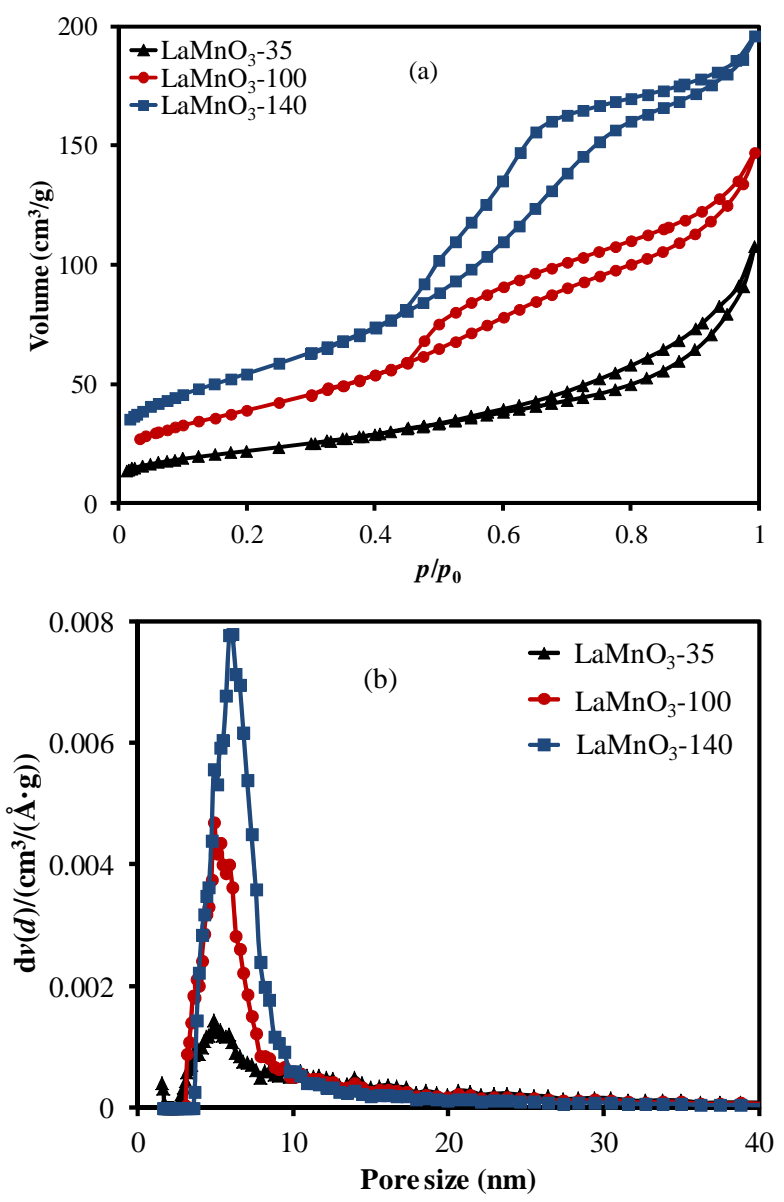

Fig. 3. $\mathrm{N}_{2}$ physisorption isotherms $\left(-196^{\circ} \mathrm{C}\right)(\mathrm{a})$ and the corresponding pore size distributions (b) of nanocast $\mathrm{LaMnO}_{3}$ perovskite oxides synthesized by use of ordered mesoporous SBA-15 silica hard templates. Pore size distributions were calculated from the adsorption branch of the isotherm using the NLDFT method.

of the final replica strongly depend on the structure parameters of the parent template used. In short, an inverse correlation between the template aging temperatures with the BET surface area, pore volume and pore size was observed. More recently, similar results were obtained by Yen et al. [35] for $\mathrm{Cu}-\mathrm{CeO}_{2}$ mixed oxides. In all these studies the authors used metal nitrates as the precursors for respective oxides. We believe that the opposite trends obtained for perovskites in the present study are probably due to the variation in pore size, pore volume and enhanced interconnectivity of the SBA-15 template,

Table 1

Structural parameters of the SBA-15 templates and nanocast perovskites obtained by performing $\mathrm{N}_{2}$ physisorption analysis at $-196^{\circ} \mathrm{C}$.

\begin{tabular}{lccc}
\hline Sample & $S_{\text {BET }}{ }^{\mathrm{a}}\left(\mathrm{m}^{2} / \mathrm{g}\right)$ & $D_{\mathrm{P}} \mathrm{b}(\mathrm{nm})$ & $V_{\mathrm{P}}{ }^{\mathrm{c}}\left(\mathrm{cm}^{3} / \mathrm{g}\right)$ \\
\hline SBA-15-35 & 738 & 5.8 & 0.66 \\
SBA-15-100 & 960 & 7.3 & 1.1 \\
$\mathrm{SBA}-15-140$ & 852 & 9.0 & 1.7 \\
$\mathrm{LaMnO}_{3}-35$ & 80 & 4.8 & 0.15 \\
$\mathrm{LaMnO}_{3}-100$ & 140 & 5.1 & 0.21 \\
$\mathrm{LaMnO}_{3}-140$ & 190 & 6.0 & 0.29 \\
\hline
\end{tabular}

a Calculated by using the BET method on the relatively low-pressure region (0.05-0.2); ${ }^{\mathrm{N}} \mathrm{NLDFT}$ pore size; ${ }^{\mathrm{c}}$ Pore volume. 
resulting from the increase in aging temperature. Larger pore volume and interconnectivity seems to be needed to facilitate a more adequate loading of the complexed precursor which consisting of a bulky large organic molecule (e.g., metal cations consist with citric acid). This results in a comparatively better structural order after the removal of the template and hence the highest value of surface area when SBA-15 aged at $140{ }^{\circ} \mathrm{C}$ was used as the hard template. Note that the isotherm of LaMnO3-140 shows a particularly well-developed mesoporosity, expressed by a sharp capillary condensation step and hysteresis loop, characteristic of large ordered cylindrical-like mesopores.

\subsection{Temperature programmed reduction of hydrogen}

The reduction behavior of metal cations in nanocast mesoporous perovskites was examined using temperature-programmed reduction by hydrogen ( $\mathrm{H}_{2}$-TPR). Because the A-site metal is non reducible under the present conditions of $\mathrm{H}_{2}$-TPR, the observed $\mathrm{H}_{2}$ consumption peaks correspond to the reduction behaviour of $\mathrm{Mn}$ ions in the perovskite structure and the observed profiles are shown in Fig. 4. Different from other perovskite compositions, complete reduction to $\mathrm{Mn}^{0}$ does not occur for $\mathrm{LaMnO}_{3}$, under the present analysis conditions $[36,37]$. For all the three samples, a broad main peak with a high temperature and a low temperature shoulders were ob-
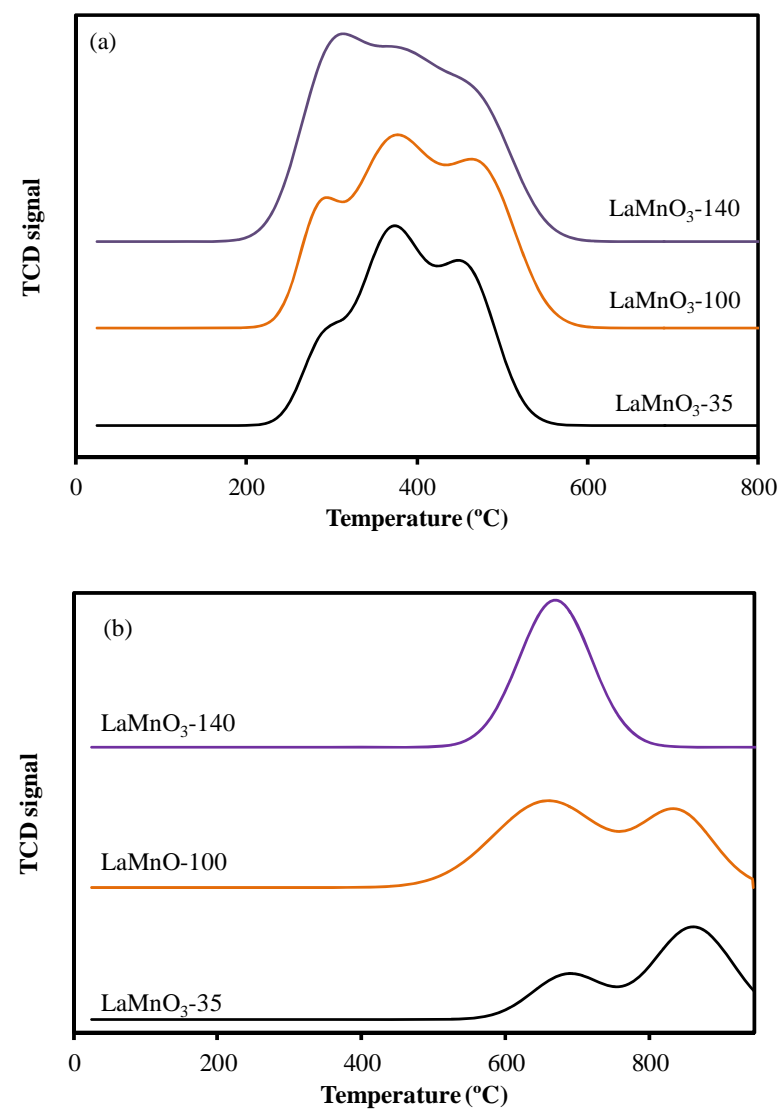

Fig. 4. $\mathrm{H}_{2}$-TPR (a) and $\mathrm{O}_{2}$-TPD (b) profiles of nanocast mesoporous $\mathrm{LaMnO}_{3}$ perovskite oxides synthesized by use of ordered mesoporous SBA-15 silica hard templates aged at different temperatures. served. The main peak can be assigned to the reduction of $\mathrm{Mn}^{3+}$ to $\mathrm{Mn}^{2+}\left(0.5 \mathrm{~mol} \mathrm{H}_{2}\right.$ per atom of $\left.\mathrm{Mn}\right)$. The low temperature shoulder clearly indicates the presence of $\mathrm{Mn}^{4+}$ resulting from the presence of over-stoichiometric oxygen as observed previously [38], whereas the high temperature shoulder suggests the presence of Mn ions that are not easily accessible. Interestingly, it was also observed that the $\mathrm{Mn}^{4+}$ content was higher for $\mathrm{LaMnO}_{3}$-140. Absence of other noticeable peaks in the TPR pattern, especially at higher temperatures indicates that a very negligible interaction, if any, exists between the reducible metal (Mn in this case) and the residual silicon species. Also significant changes in the reduction behaviour of Mn were hardly observed for any of the samples in the present study. The amounts of hydrogen consumed during the reduction of nanocast perovskites are given in Table 2 . The values of $\mathrm{Mn}^{4+}$ show a clear variation from $3 \%$ to $15 \%$, which reflects the variations in the amount of excess oxygen in the structure.

\subsection{Temperature programmed desorption of oxygen}

Information regarding the nature of oxygen atoms on nanocast $\mathrm{LaMnO}_{3}$ perovskites was obtained by recording the temperature-programmed desorption of oxygen $\left(\mathrm{O}_{2}\right.$-TPD) profiles. Two types of oxygen species are generally found to be desorbed from perovskite oxides. Desorption of oxygen bound to the surface takes place below $700{ }^{\circ} \mathrm{C}$ (designated as $\alpha-\mathrm{O}_{2}$ ), and desorption of lattice oxygen takes place at a higher temperature (designated as $\beta-\mathrm{O}_{2}$ ). In the present work two peaks were observed for $\mathrm{LaMnO}_{3}-100$ and $\mathrm{LaMnO}_{3}-35$, whereas in the case of $\mathrm{LaMnO}_{3}-140$, the high temperature peak corresponding to the $\beta-\mathrm{O}_{2}$ was negligible. Very clear increase in the intensity of the low temperature peaks $\left(\alpha-\mathrm{O}_{2}\right)$ was observed for the nanocast $\mathrm{LaMnO}_{3}$ with respect to the increase in surface area of the material (see Fig. 4). The amounts of desorbed oxygen were calculated and are listed in Table 3. Assuming $4 \mu \mathrm{mol} / \mathrm{m}^{2}$ of oxygen amounts to one monolayer, the number of desorbed monolayers were also calculated.

\subsection{Catalytic tests}

In our previous work, we clearly showed that nanocast perovskite materials were better oxidation catalysts than materials of similar compositions synthesized by other methods

Table 2

Amount of $\mathrm{H}_{2}$ consumed during $\mathrm{H}_{2}$-TPR.

\begin{tabular}{lcc}
\hline Perovskite & $\mathrm{H}_{2}$ consumed $\left(\mathrm{mol}_{\mathrm{H} 2} / \mathrm{Mn}\right)$ & $\mathrm{Mn}^{4+}(\%)$ \\
\hline $\mathrm{LaMnO}_{3}-35$ & 0.516 & 3 \\
$\mathrm{LaMnO}_{3}-100$ & 0.536 & 7 \\
$\mathrm{LaMnO}_{3}-140$ & 0.576 & 15 \\
\hline
\end{tabular}

Table 3

Amount of $\mathrm{O}_{2}$ desorbed during $\mathrm{O}_{2}$-TPD.

\begin{tabular}{lcccc}
\hline Perovskite & $\begin{array}{c}\alpha-\mathrm{O}_{2} \\
(\mu \mathrm{mol} / \mathrm{g})\end{array}$ & $\begin{array}{c}\beta-\mathrm{O}_{2} \\
(\mu \mathrm{mol} / \mathrm{g})\end{array}$ & $\begin{array}{c}\alpha-\mathrm{O}_{2} \\
\text { monolayer }\end{array}$ & $\begin{array}{c}\beta-\mathrm{O}_{2} \\
\text { monolayer }\end{array}$ \\
\hline $\mathrm{LaMnO}_{3}-35$ & 264 & 372 & 0.82 & 1.16 \\
$\mathrm{LaMnO}_{3}-100$ & 506 & 220 & 0.82 & 0.38 \\
$\mathrm{LaMnO}_{3}-140$ & 638 & - & 0.83 & - \\
\hline
\end{tabular}


[15]. The catalytic oxidation activity of the mesoporous perovskites was examined using methanol as the model compound, under the flow conditions corresponding to a gas hourly space velocity of $39100 \mathrm{~h}^{-1}$. The comparison of mesoporous $\mathrm{LaMnO}_{3}$ catalysts synthesized by varying the aging temperature of the hard template, and thus varying porosity and surface area parameters, was performed and the obtained temperature dependent conversion curves are given in Fig. 5. Clear variations in the conversion efficiencies with the values of the catalyst specific surface area were observed. For the catalyst with largest specific surface area full conversion was observed at $145^{\circ} \mathrm{C}$. As expected, an increase in full conversion temperature was observed for lower value of specific surface area. Even though some conversion was already observed near room temperature for nanocast $\mathrm{LaMnO}_{3}-100$ and $\mathrm{LaMnO}_{3}-140$, the values of conversion were slightly higher for the latter under the same conditions of temperature. Also, $\mathrm{CO}_{2}$ was the only product detected for all the catalysts, without any presence of formaldehyde or $\mathrm{CO}$, which indicates that all of these nanocast materials are highly efficient methanol oxidation catalysts.

\subsection{Kinetic studies}

Kinetic data processing was performed for the total oxidation of methanol over all three nanocast $\mathrm{LaMnO}_{3}$ catalysts. For this purpose, the temperature dependent conversions were monitored for these catalyst materials at different flow rates which resulted in gas hourly space velocities ranging from 19500 to $78200 \mathrm{~h}^{-1}$. The corresponding conversion curves obtained in the case of $\mathrm{LaMnO}_{3}-35, \mathrm{LaMnO}_{3}-100$ and $\mathrm{LaMnO}_{3}-140$ are shown in Supporting Information Fig. S.3. The conversion values at several selected temperatures were cross-plotted against the pseudo-contact time $W / F$ (in which $\mathrm{W}$ is the mass of the catalyst and $\mathrm{F}$ is the molar flow rate of methanol). This yielded a series of isothermal curves as shown in Fig. 6 (and Supporting Information Figs. S.4 and S.5). The resultant data were then fitted using the sigmoidal Eq.(1), the analytical derivatization of which gave the values of reaction rates:

$$
X=a /\left(1+b e\left(-c\left(\frac{W}{F}\right)\right)\right.
$$

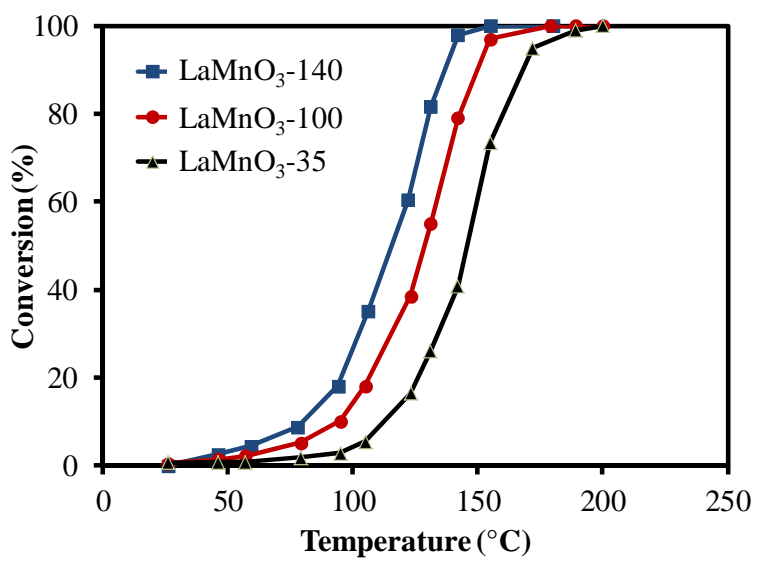

Fig. 5. Methanol conversion profiles as a function of temperature over nanocast $\mathrm{LaMnO}_{3}$ perovskites synthesized using SBA-15 silica hard template aged at different temperatures $\left(\mathrm{GHSV}=39100 \mathrm{~h}^{-1}\right)$.
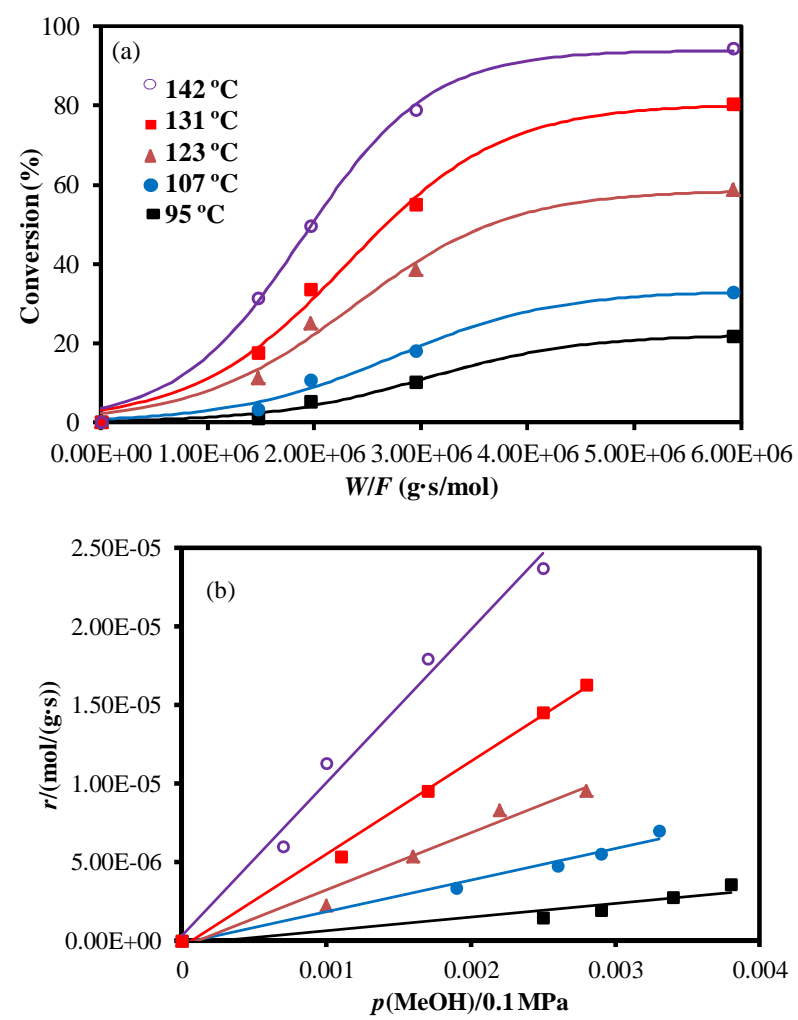

Fig. 6. Cross-plotting the values of experimental conversions at selected temperatures as a function of pseudo-contact time obtained for nanocast $\mathrm{LaMnO}_{3}-100$ (a). Points represent experimental data, and lines are calculated by using Eq (1). The numerical values of rates obtained in each case are represented as a function of the partial pressure of methanol (b).

in which $X$ is the conversion of methanol and $a, b$, and $c$ are nonlinear regression parameters.

The numerical values of the reaction rates $(r)$ thus obtained were further fitted using Eq.(2) and the values of rate constants $(k)$ were obtained. This equation which was previously proposed by Arai et al. [4] assumes the participation of only lattice oxygen in the catalytic process and the corresponding fit is shown in Fig. 6.

$$
r=\mathrm{d} X / \mathrm{d}(W / F)=k \cdot p(\mathrm{MeOH})
$$

The values of pre-exponential factor (A) and activation energy $\left(E_{\mathrm{a}}\right)$ for the nanocast catalysts were determined from the Arrhenius plot by performing linear regression analysis as shown in Fig. 7. These values are reported in Table 4. The values of $E_{\text {a }}$ were found to remain essentially constant irrespective of the surface area of the catalyst used. Interestingly, a linear correlation was found to exist between the pre-exponential factors and the values of specific surface area of the catalysts as shown in Fig. 7. This indicates that the specific activity per unit surface area remains the same for all the catalysts used in the present study.

The residual Si species remaining in these nanocast perovskites, that cannot be completely removed after the multiple template removal steps ( 3 times using $\mathrm{NaOH}(2 \mathrm{~mol} / \mathrm{L})$ ), can cause several effects towards the efficiency of these materials. Previous studies on such residual species indicated a negative contribution on the value of specific surface area [39]. On the 

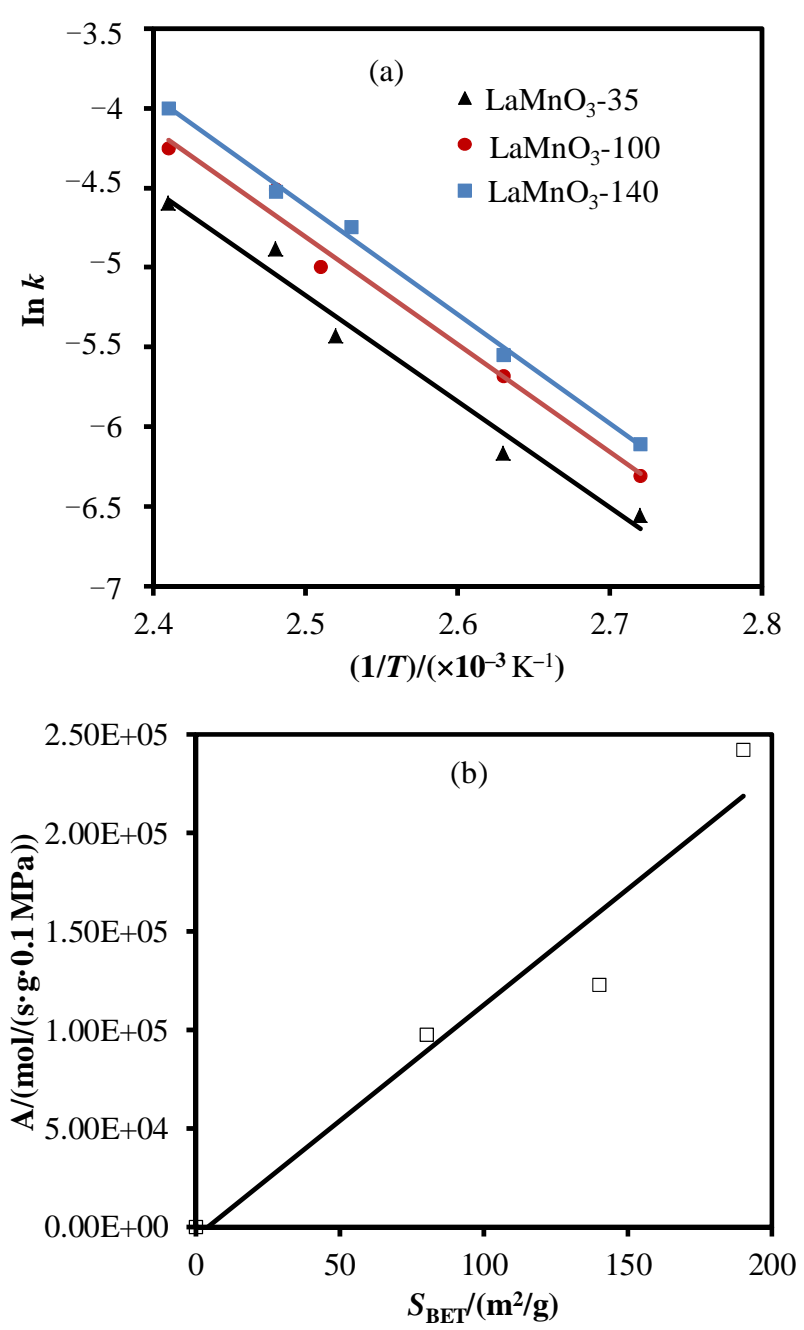

Fig. 7. Arrhenius plots for the rate constant $k$ obtained for nanocast $\mathrm{LaMnO}_{3}-35, \mathrm{LaMnO}_{3}-100$ and $\mathrm{LaMnO}_{3}-140$ (a); The linear correlation between the pre-exponential factor and the specific surface area (b).

other hand, these residual $\mathrm{Si}$ species could as well induce a positive contribution by providing improved stability to these nanoporous framework structures. Also, it can interact with the active phase and thereby affect the efficiency of these materials. However, to confirm the existence of either of these aforementioned effects on the catalytic activity of the nanocast perovskites, more information regarding the exact nature of the residual Si species is necessary. Studies are being conducted in this direction.

As mentioned above, Arai et al. [4] Eq. (2) assumes that lattice oxygens, usually designated as $\beta$-oxygens, are utilized in the catalytic oxidation process. However as shown in Table 3 , the $\beta$-oxygen content of the nanocast $\mathrm{LaMnO}_{3}$ catalysts decreases with the ageing temperature of the template, even reaching the zero value for $\mathrm{LaMnO}_{3}-140$ which is the most active catalyst. This suggests that this high temperature desorbing oxygen species is not the active oxygen. On the other hand, the other oxygen species designated here as $\alpha$-oxygen desorbs over a temperature range comprised between 580 and $720^{\circ} \mathrm{C}$
Table 4

Kinetic parameters obtained for total oxidation of methanol over nanocast perovskites.

\begin{tabular}{lcc}
\hline Perovskite & ${ }^{\mathrm{a}} E_{\mathrm{a}} /(\mathrm{kcal} / \mathrm{mol})$ & ${ }^{\mathrm{b}} A /(\mathrm{mol} \cdot \mathrm{g} \cdot 0.1 \mathrm{MPa})^{-1}$ \\
\hline $\mathrm{LaMnO}_{3}-35$ & 13.49 & $9.7 \mathrm{e}^{4}$ \\
$\mathrm{LaMnO}_{3}-100$ & 13.52 & $12.3 \mathrm{e}^{4}$ \\
$\mathrm{LaMnO}_{3}-140$ & 13.51 & $24.2 \mathrm{e}^{4}$ \\
\hline
\end{tabular}

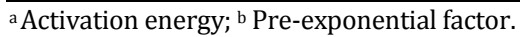

(Fig. 4). This is quite high for an adsorbed oxygen species, which suggests that here the so-called $\alpha$-oxygen is likely to be a mere surface lattice oxygen. This is corroborated by the number of monolayers of this species remaining essentially constant and close to one in the three solids (Table 3). These oxygens being the active ones in the oxidation process would thus also be coherent with the observed proportionality of reaction rate constants being linearly correlated to specific surface area (Fig. 7).

As indicated in Table 4, the observed activation energy is not affected by the template ageing temperature and therefore not affected by specific surface area. The value of $13.5 \mathrm{kcal} / \mathrm{mol}$ seems a little low for a process having surface reaction as the rate limiting step. This raises the possibility of internal diffusion being controlling the overall reaction rate. Careful examination of our kinetic results allows however rejecting this hypothesis. The occurrence of a limitation by internal diffusion is represented using an effectiveness factor $\eta$ in the rate equation:

$$
r=\eta k p(\mathrm{MeOH})
$$

In absence of a significant methanol concentration gradient, the effectiveness factor is equal to one and Eq. (3) is reduced to Eq. (2). The value of $\eta$ is determined by the Thiele modulus which for a first order reaction is expressed as

$$
\varphi=R \sqrt{\frac{k_{0} S_{0}}{D_{e f f}}}
$$

where $R$ is the particle diameter, $\mathrm{k}_{0}$ is the rate constant expressed per unit volume $\left(\mathrm{mol} /\left(\mathrm{s} \cdot \mathrm{m}^{3}\right), S_{0}\right.$ the specific surface area $\left(\mathrm{m}^{2} / \mathrm{m}^{3}\right)$ and $D_{\text {eff }}(\mathrm{m} / \mathrm{s})$ is the effective diffusion coefficient of methanol in the solid catalyst.

The effectiveness factor $\eta$ is close to one for $\varphi$ sufficiently small (typically <1). An estimate of $\varphi$ using the highest rate value given in Fig. 6 yields of value of 0.3 . It is therefore concluded that internal diffusion is not affecting the rate values reported.

This conclusion is coherent with the observation of a constant reaction rate per unit surface area in the three catalysts. The large differences in pore volume (Table 1 and Fig. 3) which would affect the effective diffusion coefficient would change the Thiele modulus in the different catalysts. Thus if $\varphi$ was higher than one its different values would affect internal diffusion and the effectiveness factor.

\section{Conclusions}

In conclusion, we have synthesized a series of mesoporous perovskite oxides with lanthanum in the A site and manganese 
in the B site by using the nanocasting method and SBA-15 aged at three different temperatures as hard templates. These materials were found to display extremely high specific surface area. Also a correlation between the aging temperature of the template and the specific surface area was observed. The observed values of activation energy for the catalysts were low and remained constant for all the catalysts under the present conditions of study. Furthermore, apart from the variations in the textural parameters of these materials, the specific activity for methanol oxidation per unit surface area remains the same for all these nanocast perovskites. Further work is in progress to determine the nature of residual Si species on these nanocast perovskites that cannot be removed during the template removal step. We believe that this is necessary to determine the role of these residual species on the efficiency of such nanocast materials.

\section{References}

[1] A. O'Malley, B. K. Hodnett, Catal. Today, 1999, 54, 31.

[2] T. Garcia, B. Solsona, D. Cazorla-Amoros, A. Linares-Solano, S. H. Taylor, Appl. Catal. B, 2006, 62, 66.

[3] C. H. Kim, G. Qi, K. Dahlberg, W. Li, Science, 2010, 327, 1624.

[4] H. Arai, T. Yamada, K. Eguchi, T. Seiyama, Appl. Catal., 1986, 26, 265.

[5] V. C. Belessi, P. N. Trikalitis, A. K. Ladavos, T. V. Bakas, P. J. Pomonis, Appl. Catal. A, 1999, 177, 53.

[6] H. Taguchi, S. Yamada, M. Nagao, Y. Ichikawa, K. Tabata, Mater. Res. Bull., 2002, 37, 69.

[7] S. O'Brien, L. Brus, C. B. Murray, J. Am. Chem. Soc., 2001, 123, 12085.

[8] J. Kirchnerova, D. Klvana, Solid State Ionics, 1999, 123, 307.

[9] S. Kaliaguine, A. Van Neste, V. Szabo, J. E. Gallot, M. Bassir, R. Muzychuk, Appl. Catal. A, 2001, 209, 345.

[10] H. F. Yang, D. Y. Zhao, J. Mater. Chem., 2005, 15, 1217.

[11] A. H. Lu, F. Schuth, Adv. Mater., 2006, 18, 1793.

[12] H. Yen, Y. Seo, R. Guillet-Nicolas, S. Kaliaguine, F. Kleitz, Chem.
Commun., 2011, 47, 10473.

[13] F. Jiao, A. Harrison, A. H. Hill, P. G. Bruce, Adv. Mater., 2007, 19, 4063.

[14] Y. G. Wang, J. W. Ren, Y. Q. Wang, F. Y. Zhang, X. H. Liu, Y. Guo, G. Z. Lu, J. Phys. Chem. C, 2008, 112, 15293.

[15] M. M. Nair, F. Kleitz, S. Kaliaguine, ChemCatChem, 2012, 4, 387.

[16] H. Tüysüz, C. W. Lehmann, H. Bongard, B. Tesche, R. Schmidt, F. Schüth, J. Am. Chem. Soc., 2008, 130, 11510.

[17] M. Tiemann, Chem. Mater., 2008, 20, 961.

[18] F. Jiao, K. M. Shaju, P. G. Bruce, Angew. Chem. Int. Ed., 2005, 44, 6550.

[19] B. Z. Tian, X. Y. Liu, L. A. Solovyov, Z. Liu, H. F. Yang, Z. D. Zhang, S. H. Xie, F. Q. Zhang, B. Tu, C. Z. Yu, O. Terasaki, D. Y. Zhao, J. Am. Chem. Soc., 2004, 126, 865.

[20] F. Jiao, A. Harrison, J. C. Jumas, A. V. Chadwick, W. Kockelmann, P. G. Bruce, J. Am. Chem. Soc., 2006, 128, 5468.

[21] W. C. Li, M. Comotti, A. H. Lu, F. Schüth, Chem. Commun., 2006, 1772.

[22] R. K. C. de Lima, M. S. Batista, M. Wallau, E. A. Sanches, Y. P. Mascarenhas, E. A. Urquieta-Gonzalez, Appl. Catal. B, 2009, 90, 441.

[23] Y. C. Du, Q. Meng, J. S. Wang, J. Yan, H. G. Fan, Y. X. Liu, H. X. Dai, Microporous Mesoporous Mater., 2012, 162, 199.

[24] S. P. D. Marques, A. L. Pinheiro, T. P. Braga, A. Valentini, J. M. Filho, A. C. Oliveira, J. Mol. Catal. A, 2011, 348, 1.

[25] Z. Sarshar, F. Kleitz, S. Kaliaguine, Energy Environ. Sci., 2011, 4, 4258.

[26] M. Choi, W. Heo, F. Kleitz, R. Ryoo, Chem. Commun., 2003, 1340.

[27] A. V. Neimark, P. I. Ravikovitch, Microporous Mesoporous Mater., 2001, 44-45, 697.

[28] J. Landers, G. Yu Gor, A. V. Neimark, Colloids Surf. A, 2013, 437, 3.

[29] F. Kleitz, F. Bérubé, R. Guillet-Nicolas, C. M. Yang, M. Thommes, J. Phys. Chem. C, 2010, 114, 9344.

[30] A. Galarneau, H. Cambon, F. Di Renzo, R. Ryoo, M. Choi, F. Fajula, New J. Chem., 2003, 27, 73.

[31] M. Kruk, M. Jaroniec, C. H. Ko, R. Ryoo, Chem. Mater., 2000, 12, 1961.

[32] A. Rumplecker, F. Kleitz, E. L. Salabas, F. Schüth, Chem. Mater., 2007, 19, 485.

\section{Graphical Abstract}

Chin. J. Catal., 2016, 37: 32-42 doi: 10.1016/S1872-2067(15)60909-3

Pore structure effects on the kinetics of methanol oxidation over nanocast mesoporous perovskites

Mahesh M. Nair, Freddy Kleitz, Serge Kaliaguine*

Université Laval, Canada
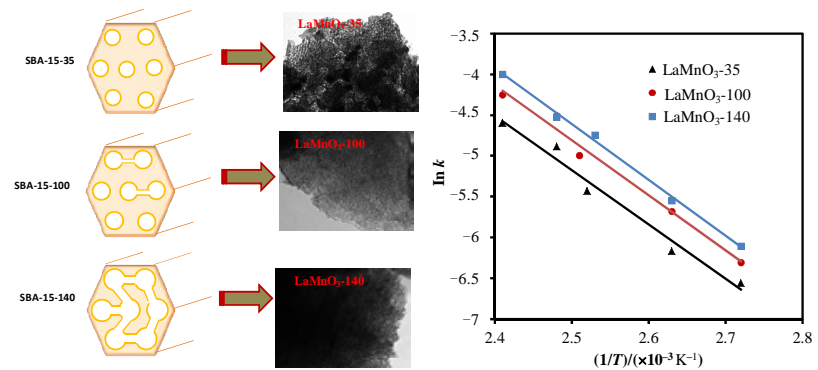

Changing SBA-15 template aging temperature which affects the pore structure of the mesoporous perovskite does not change activation energy. Only preexponential factor is changed proportionally to specific surface area. 
[33] F. Jiao, A. H. Hill, A. Harrison, A. Berko, A. V. Chadwick, P. G. Bruce, J. Am. Chem. Soc., 2008, 130, 5262.

[34] H. Tuysuz, M. Comotti, F. Schuth, Chem. Commun., 2008, 34, 4022.

[35] H. Yen, Y. Seo, S. Kaliaguine, F. Kleitz, Angew. Chem. Int. Ed., 2012, $51,12032$.

[36] S. Royer, H. Alamdari, D. Duprez, S. Kaliaguine, Appl. Catal. B,
2005, 58, 273.

[37] A. Baiker, P. E. Marti, P. Keusch, E. Fritsch, A. Reller, J. Catal., 1994, $146,268$.

[38] B. Levasseur, S. Kaliaguine, Appl. Catal. A, 2008, 343, 29.

[39] G. Marban, A. B. Fuertes, T. Valdés-Solis, Microporous Mesoporous Mater., 2008, 112, 291.

\title{
孔结构对纳米浇注的中孔钲钛矿上甲醇氧化反应动力学的影响
}

\author{
Mahesh M. Nair ${ }^{\text {a }}$, Freddy Kleitz ${ }^{\text {a }}$, Serge Kaliaguine ${ }^{\text {b,* }}$ \\ a拉瓦尔大学化学系Matériaux Avancés研究中心(CERMA), 魁北克, G1V 0A6, 加拿大 \\ $\mathrm{b}^{\mathrm{b}}$ 拉瓦尔大学化工系, 魁北克, G1V 0A6, 加拿大
}

\begin{abstract}
摘要: 限制工业有毒气体(如挥发性有机化合物)的排放是当今社会主要的挑战之一. 因此, 迫切需要开发出消除污染物、且 不造成二次污染的环境友好技术. 其中热燃烧技术比较有效, 但通常该过程会采用贵金属催化剂以实现低温高活性. 由于 贵金属催化剂的成本较高, 不利于工业应用, 因此, 人们一直致力于研究和开发新型材料以替代贵金属催化剂. 研究发现, 在许多部分氧化或完全氧化反应(特别是烃类或挥发性有机物的氧化反应)中, 钙钛矿类复合金属氧化物 $\left(\mathrm{ABO}_{3}\right)$ 具有与贵 金属类似的催化性能. 但是该材料的制备需在高温 $\left(>700^{\circ} \mathrm{C}\right)$ 条件下进行, 使得其比表面积 $\left(<30 \mathrm{~m}^{2} / \mathrm{g}\right)$ 很低, 因而限制了其 应用. 可见, 欲使该材料在工业上得到广泛应用, 必须在制备技术上实现很大的突破, 即制得高比表面积的钙钛矿类材料. 已有人通过在 $200{ }^{\circ} \mathrm{C}$ 下焙烧成功地制备了比表面积为 $100 \mathrm{~m}^{2} / \mathrm{g}$ 的钻钛矿氧化物, 但继续提高焙烧温度, 所制样品的比表面 积下降.

在过去20年中, 中孔氧化硅及随后众多中孔材料的成功制备, 使得合成具有极高比表面积的非硅基材料(如碳, 金属氧 化物, 和碳化物等)成为可能. 在这些材料的制备方法中, 纳米浇铸法因其特别适用于制备具有高比表面积的单金属或单金 属氧化物而备受青睐. 采用纳米浇铸法已经成功制得一系列材料, 并用于很多催化反应中. 但文献报道大多只局限于温 度、催化剂组成或比表面积对其活性的影响. 为了能将这些材料成功用于工业应用, 需要对其表面反应机理和相关反应动 力学进行深入的研究.

最近, 本课题组采用纳米浇铸法制备了高比表面积的中孔钻钛矿类氧化物, 并考察了它们的催化性能. 结果表明, 在各 种气相反应中, 所制纳米浇注的钙钠矿类氧化物具有比相应体相氧化物更高的催化效率. 基于此, 本文以在不同温度老化 的SBA-15为硬模板, 采用纳米浇铸法制备高比表面积的 $\mathrm{LaMnO}_{3}$ 材料, 运用X-射线衍射、 $\mathrm{N}_{2}$ 吸附-脱附、透射电镜、程序升 温还原和 $\mathrm{O}_{2}$-程序升温脱附等方法分析所制材料的晶相、织构、表面和氧化还原等性质, 考察了其孔结构参数对其催化甲 醇完全氧化反应性能和动力学的影响, 以深入理解该类材料的催化性能. 结果表明, 以 $35,100,140{ }^{\circ} \mathrm{C}$ 老化制得的SBA- 15 为模板剂, 成功地制得了 $\mathrm{La}$ 在 $\mathrm{A}$ 位, $\mathrm{Mn}$ 在B位的一系列 $\mathrm{LaMnO}_{3}$ 材料, 它们具有可调控的比表面积 $\left(80-190 \mathrm{~m}^{2} / \mathrm{g}\right)$; 同时, 材料 的比表面积与所用硬模板剂的老化温度存在很好的关联, 且比表面积最大的样品具有最高的催化活性. 测量了各催化剂 在不同空速(19500-78200 $\mathrm{h}^{-1}$ )条件下甲醇氧化反应结果, 从而得到了各催化剂的速率常数, 发现它们随着催化剂的比表面 积而变化. 再结合阿伦尼乌斯方程, 采用线性回归法测得了所制备的三个催化剂上该方程的指前因子和表观活化能; 发现 在所考察的反应条件下, 所有催化剂上反应的表观活化能较低, 且保持不变. 另外, 指前因子与催化剂比表面积之间存在 线性关系, 表明尽管各催化剂的比表面积不同, 但单位比表面积的甲醇氧化的比活性是相同的. 由于在制备过程中很难除 去残余的 $\mathrm{Si}$ 物种, 因此未来工作中我们将进一步考察残余物种对纳米浇注的钻针矿类材料性质的影响.
\end{abstract}

关键词: 中孔钙钛矿; 高比表面积; 纳米浇注法; 甲醇氧化反应; 动力学

收稿日期: 2015-03-21. 接受日期: 2015-05-03. 出版日期: 2016-01-05.

*通讯联系人. 传真: +1-418-6563810; 电子信箱: serge.kaliaguine@gch.ulaval.ca

本文的英文电子版由Elsevier出版社在ScienceDirect上出版(http://www.sciencedirect.com/science/journal/18722067).

\section{Supporting Information}

$\mathrm{N}_{2}$ physisorption isotherms and corresponding pore size distributions determined by the NLDFT method for ordered mesoporous SBA-15 templates, Comparison between the experimental $\mathrm{N}_{2}$ physisorption isotherms with the theoretical ones calculated using the NLDFT method for nanocast $\mathrm{LaMnO}_{3}$, Temperature dependent methanol conversion profiles at various space velocities, cross plotting of experimental conversions as a function of pseudo contact time for $\mathrm{LaMnO}_{3}-35$ and $\mathrm{LaMnO}_{3}-140$, representation of reaction rates as a function of methanol partial pressure for $\mathrm{LaMnO}_{3}-35$ and $\mathrm{LaMnO}_{3}-140$. 

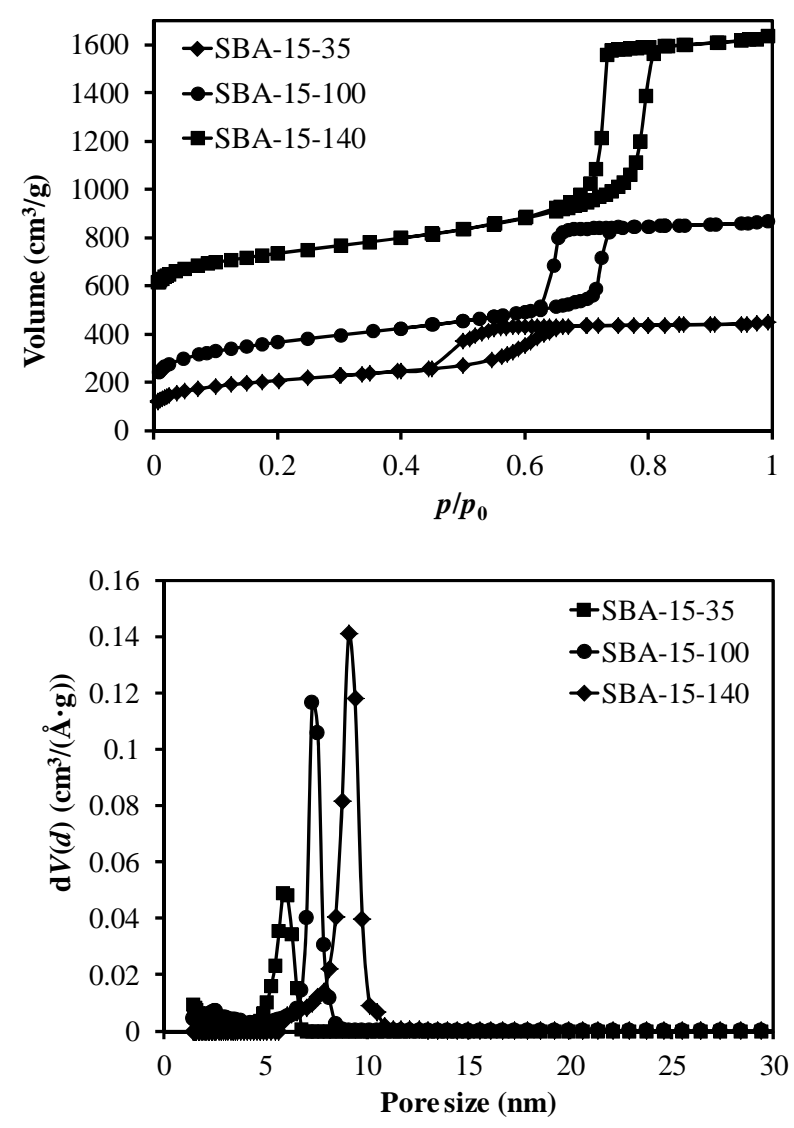

Fig. S1. $\mathrm{N}_{2}$ physisorption isotherms $\left(-196{ }^{\circ} \mathrm{C}\right)$ and the corresponding pore size distributions (bottom) of ordered mesoporous SBA-15 silica hard templates. Pore size distributions were calculated from the adsorption branch of the isotherm using the NLDFT method.

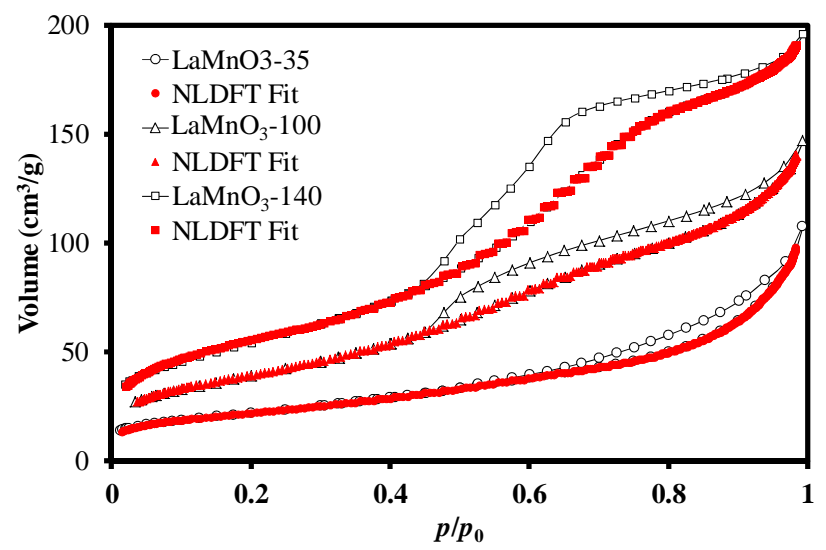

Fig. S2. $\mathrm{N}_{2}$ physisorption isotherms $\left(-196^{\circ} \mathrm{C}\right)$ and the corresponding NLDFT theoretical isotherms (colour) of nanocast $\mathrm{LaMnO}_{3}$ perovskite oxides synthesized by use of ordered mesoporous SBA-15 silica hard templates.
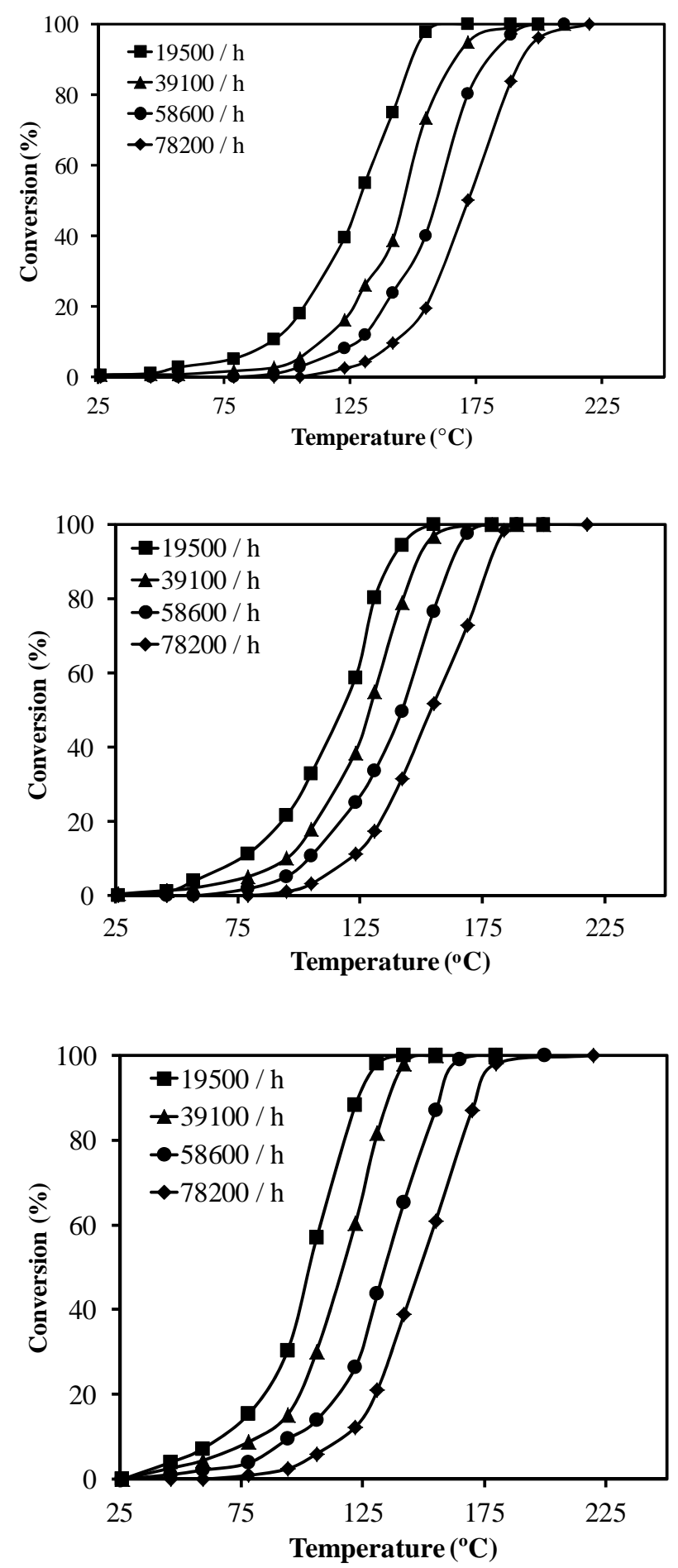

Fig. S3. Temperature dependent conversion profiles for the total oxidation of methanol over nanocast $\mathrm{LaMnO}_{3}-35$ (top) $\mathrm{LaMnO}_{3}-100$ (middle) and $\mathrm{LaMnO}_{3}-140$ (bottom) at different space velocities. 

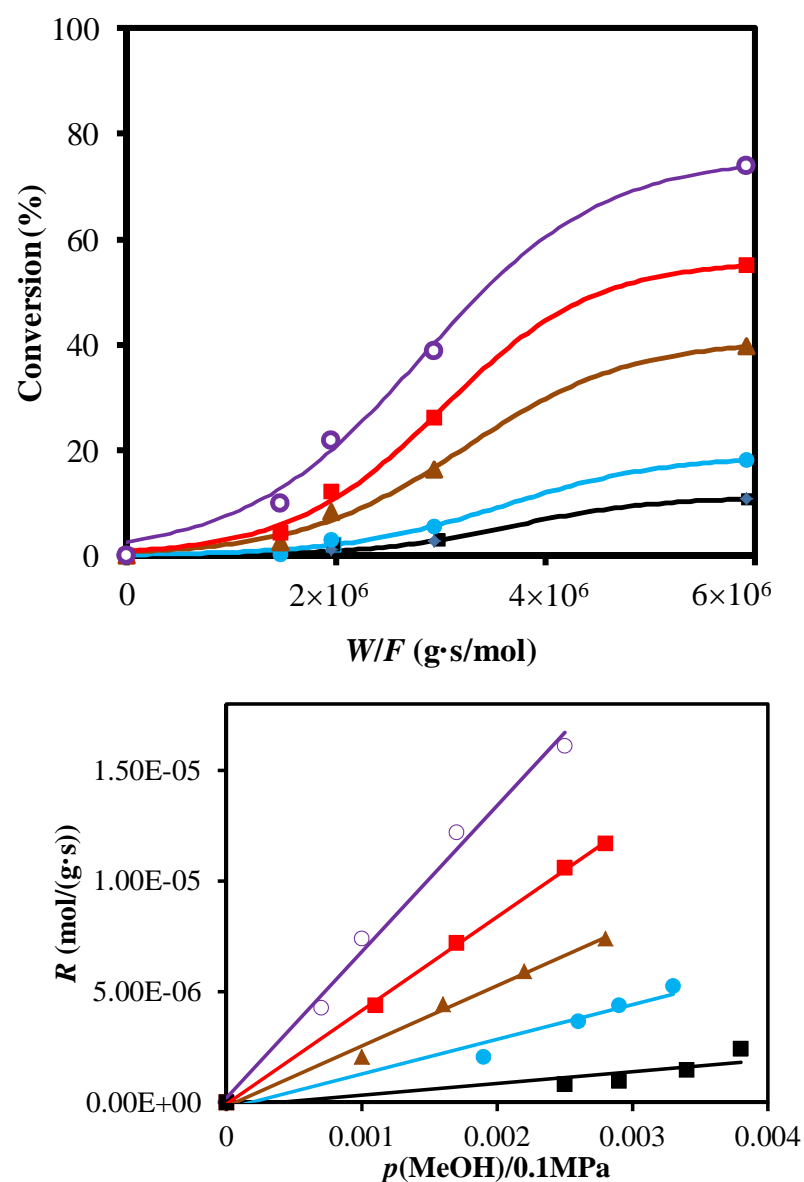

Fig. S4. Cross-plotting the values of experimental conversions at selected temperatures as a function of pseudo-contact time obtained for nanocast $\mathrm{LaMnO}_{3}-35$. Points represent experimental data, and lines are calculated by using Eq. (1). The numerical values of rates obtained in each case are represented as a function of the partial pressure of methanol (bottom).
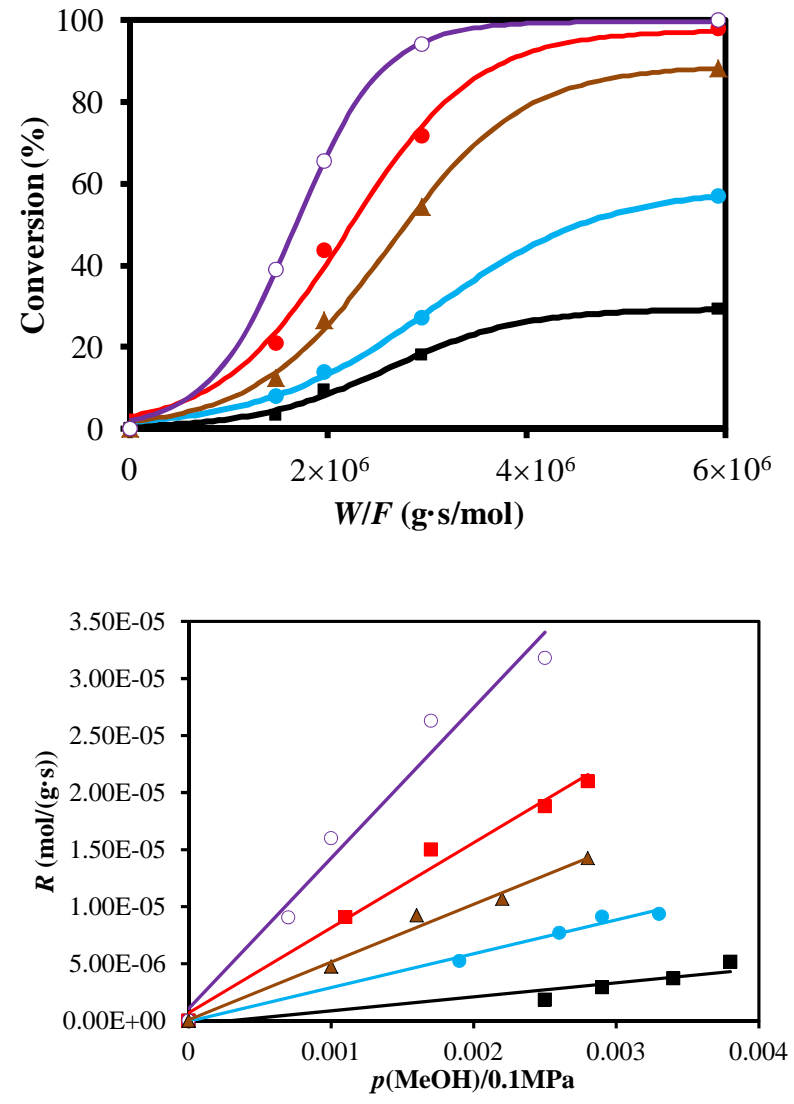

Fig. S5. Cross-plotting the values of experimental conversions at selected temperatures as a function of pseudo-contact time obtained for nanocast $\mathrm{LaMnO}_{3}-140$. Points represent experimental data, and lines are calculated by using Eq. (1). The numerical values of rates obtained in each case are represented as a function of the partial pressure of methanol (bottom). 